\title{
Identification and Elimination of Several Misconceptions of University Level Students Regarding the Misconceptions in Science Course
}

\author{
Gamze Dolu and Handan Ürek \\ Elementary Science Education Department, Necatibey Education Faculty, \\ Balıkesir University
}

\section{Abstract}

The present study is based on identification and elimination of several misconceptions of university level students regarding chemistry topics. For this reason, the static-group pre-test-post-test design was implemented with 52 teacher candidates. Regarding the content of the study, the experimental group participants opted for "Misconceptions in Science" course whereas the control group selected "Physics in environment" course in terms of elective courses. Data was collected through a form which consisted of 3 open-ended statements during the research process. In addition, an evaluation form was prepared to determine the opinions of the experimental group on the course. As a result of the study, the pre-test analyses revealed several misconceptions which all the participants have, whereas the post-test results indicated that "Misconceptions in science" course was effective in the elimination of experimental group's misconceptions. Also, the course was found to be necessary and efficient. Delayed post-test results justified the resistivity of the misconceptions of the experimental group members, although they had been performing their jobs as in-service science teachers.

Key words: chemistry; conceptual change discussion.

\section{Introduction}

Since general chemistry topics provide a basis for learning chemistry and for various topics related to the fields of physics and biology at university level, students should have correct conceptions regarding that area. On the other hand, Zoller (1990) reports 
that freshman chemistry is believed to be the most problematic traditional science discipline due to learning difficulties, misconceptions and misunderstanding. Besides, chemistry topics provide a number of common terms related to physics and/or biology. Hence, the meanings of those common concepts should be conceptualized and transferred to students correctly in order to build relationships in the right way (Sinan, 2009). However, students might form scientific knowledge in their minds which is specific to them and which is resistant to change, therefore causing alternative conceptions. Those alternative conceptions may contradict scientific knowledge totally, partially or may not be related to scientific conception at all.

When literature is examined, there are a number of studies focusing on the identification of misconceptions of students in terms of chemistry subjects (Azizoğlu \& Alkan, 2002; Karamustafaoğlu, Ayas, \& Coştu, 2002; Akgün, Gönen \& Yllmaz, 2005; Nakiboğlu \& Arık, 2006; Karaer, 2007; Kalın \& Arıkıl, 2010; Ağgül Yalçın, 2011). The aforementioned studies were based on the identification process of misconceptions of university level students who were teacher candidates. All conducted research studies have revealed that a significant number of undergraduate students have several misconceptions. However, rather than emphasizing the identification of alternative conceptions (Tao \& Gunstone, 1999), understanding of the process of conceptual change has been emphasized instead.

Conceptual change is defined as the ability to restructure the students' prior knowledge based on daily life experience and lay culture (Vosniadou, 2007). There are indispensable conditions that lead to a conceptual change in students, such as dissatisfaction, intelligibility, plausibility, and fruitfulness (Posner, Strike, Hewson \& Gertzog, 1982). As stated by Hewson and Hewson (1983), this process is not about providing the students with new information; instead, it involves the interaction of new knowledge with the existing knowledge. Various authors most frequently analyse conceptual change in two ways: either as (1) weak knowledge restructuring, assimilation or conceptual capture or (2) strong/radical knowledge restructuring, accommodation or conceptual exchange by adding the uncertainty of simple accretion of knowledge to this process or not adding it (Duit \& Treagust, 2003). Epistemological, classical and alternative aspects have also been discussed (Duit \& Treagust, 2003).

When the effects of different methods on conceptual change were considered, the following methods were reported to be efficient in the elimination of misconceptions: computer-aided 3D teaching materials (Kahraman \& Demir, 2011), computeraided materials and 5E model (Saka \& Akdeniz, 2006), explanatory story (Ayvacı \& Çoruhlu, 2009), integrative teaching method (Tezcan \& Salmaz, 2005), concept maps (Karamustafaoğlu, Ayas, \& Coştu, 2002), and cooperative learning (Taşdemir \& Sarikaya, 2005). Among these methods, discrepant events which can be either demonstrations or phenomena have been reported to achieve conceptual change in students' minds by conflicting their existing knowledge in this process (Tao \& Gunstone, 1999). 
Despite the fact that teachers are one of the main elements that drive the learning process, the research determined various problematic cases related to science teachers and science teacher candidates. These problem areas include a lack of or insufficient content knowledge (Kahyaoğlu \& Yavuzer, 2004; Canbazoğlu, Demirelli, \& Kavak, 2010) and deficiencies in concept teaching (Halim \& Meerah, 2002; Güneş, Dilek, Demir, Hoplan, \& Çelikoğlu, 2010). Karamustafaoğlu' s literature-based examination indicated that theoretical work had been emphasized more than practice and application-based work, and he highlighted the significance of making room for practice and application in academic sites and seminars in order to achieve academic improvement of science teachers (2009).

When those findings in the literature are considered, it is obvious that there are a number of limitations in concept teaching in science education. We believe that the efficiency of the methods utilized in teacher education might contribute to their conceptualization, in addition to providing inspiration for their future career as teachers. Hence, this study does not aim only to identify the several misconceptions which the participants have, but also to demonstrate the efficiency of a method - Conceptual Change Discussion (CCD) Method - in terms of eliminating these misconceptions. Thus, practical work will be mentioned in relation to concept teaching, which will contribute to teacher candidates becoming more experienced and well-informed. Also, it has been seen in the literature that there are a limited number of studies conducted using the CCD method. Additionally, the categories used in data analyses are expected to be helpful for similar studies. Thus, the study intends to contribute to science education substantially. The aims of the study are: (i) to identify the misconceptions of the participants related to several chemistry topics; (ii) to conduct the CCD method; (iii) to determine the effect of CCD method on students who select Misconceptions in Science Course (MISC), and (iv) to test the resistance of misconceptions. The research question is as follows: What are the participants' misconceptions regarding (a) attraction force between proton and electron; (b) not mixing several liquids of different density with one another; (c) dynamic equilibrium?

\section{Methods \\ Participants}

A total of 52 students in their $3^{\text {rd }}$ and $4^{\text {th }}$ years at Education Faculty - Elementary Science Education Department, within one of the state universities in the western part of Turkey participated in the study. Forty of the participants were female, whereas 12 of them were male students. Elementary Science Education Programme is a 4-year undergraduate programme in Turkey and the curriculum requires those students to take 4 elective courses during their education. One of those elective courses is taken in the $2^{\text {nd }}$ year whereas 3 of them are taken in the $4^{\text {th }}$ year. If the student's grade point average is satisfactory, those 3 elective courses can also be taken earlier in the $3^{\text {rd }}$ year. In this study, 30 of the participants were in their $3^{\text {rd }}$ year at university, while 22 of them 
were senior class students. The study sample was formed using a purposeful sampling method (Büyüköztürk, Çakmak, Akgün, Karadeniz, \& Demirel, 2010, p. 89).

\section{Procedure}

The static-group pre-test-post-test design from weak experimental designs was conducted in order to answer the research questions (Büyüköztürk, Çakmak, Akgün, Karadeniz, \& Demirel, 2010, p. 200). In this study, a half of the participants $(n=26)$ were included in the experimental group. Those students selected MISC in terms of elective courses, whereas the other half $(n=26)$ of students formed the control group. They took another elective course - Physics in the Environment Course (PIEC), which was provided simultaneously. The study was based on the investigation of the effects of CCD method used during one semester in which the course, MISC, was being conducted. At the beginning of the semester, the students in the experimental group were provided with the topics for each week to do research on articles and carry out any necessary studies before coming to class. The topics included in this study can be listed as follows: (i) Particulate nature of matter, (ii) Solutions, (iii) States of matter.

During that semester, the students were given a test at the beginning of the course, which consisted of scientifically correct and incorrect statements and were asked to complete it. Upon completion, those tests were exchanged among the students. Their responses and reasons behind their responses were discussed in the class, considering various aspects and with the guidance of the course instructor. Afterwards, scientific explanations were introduced by the course instructor and students' opinions and comments were shared. Thus, the students were firstly dissatisfied with their incorrect answers. Then, they gained intelligible, plausible and fruitful knowledge. During this process, students marked scientifically correct and incorrect responses with colourful pens in order to check the conceptualization of their peers before instruction. The class ended with discussion on the body of literature regarding students' research on various articles. On the other hand, the students in the control group did not receive such instruction. Instead, they studied PIEC which focused on the interpretation of the basic concepts of the physics from daily life during the semester.

Based on this perspective, the research was conducted in 3 parts:

\section{The First Part of the Study}

In order to determine the current conceptions of the participants, data gathering forms that consisted of 3 statements were given to all participants in the form of a pre-test at the beginning of semester, before conducting MISC and PIEC.

\section{The Second Part of the Study}

After applying the pre-test, the researchers conducted the MISC with the experimental group of students using the CCD method. Nussbaum and Novick had utilized the CCD method in the elimination of students' misconceptions related to particular structures of gases (1982). The stages of CCD are listed in further text (online MEB, 2012). It 
allows students to (i) be aware of pre-conceptions; (ii) explain and test the concepts or hypotheses; (iii) meet situations in which students' pre-conceptions cannot be utilized to explain them; (iv) be aware of the discrepancy with the help of discrepant event; (v) build their knowledge with the help of their inferences or presented information; (vi) comprehend that the new concepts are stronger than the old ones; (vii) feel that they develop and improve mentally; (viii) trust themselves and their abilities; (ix) control scientific comprehension in terms of conceptual aspects. In addition, it develops inquiry skills of the students. As can be concluded from the stages mentioned above, both cognitive and affective developments of students are encouraged.

The MISC required students to carry out brief research on that day's topic and bring an article to the classroom. During the course, students were given a test in order to diagnose their misconceptions about the topic at the beginning. Afterwards, different students' responses were read as examples and followed by discussion on whether they could be correct or incorrect, using CCDs. Hence, students could face their misconceptions. In addition, a teacher presentation was provided to help students build the knowledge in their minds. At the end of the course, the articles which were brought by students were summarized in order to expand students' knowledge. The same data gathering form was administered to the students in the $5^{\text {th }}$ week to make an inter-test analysis of the course. The students' task was the same as in the pre-test. By the time the inter-test was administered, two out of three research topics had been covered in the class. The reason for implementing the inter-test was to see whether there were any improvements in students' conceptions in comparison to the pre-test results.

\section{The Third Part of the Study}

At the end of the semester, a data gathering form was applied as the post-test to all students, both in the experimental and the control group. The effectiveness of the MISC was expected to be revealed with the help of post-test results by comparing two groups. Also, the students in the experimental group were asked to evaluate the MISC in all aspects, using the evaluation form.

The data gathering form was used with the experimental group participants in a form of a delayed post-test two and a half years after the research had been carried out at university. The participants were contacted via online resources in order to make them aware of the aim of the study and the significance of their participation in this delayed post-part of the study. Thus, the resistance of the misconceptions was checked although the participants had been working as science teachers in various elementary schools in Turkey. At that time, the work experience of the participants as science teachers ranged from 1 to 2 years.

\section{Data Gathering Form}

Three statements were selected among the tests prepared for the MISC classes in order to collect the data for this study. Those statements, which were constructed after literature had been reviewed, are as follows: 
(1) Protons attract closer electrons more than the distant ones.

(2) The reason for several liquids not mixing with one another is the fact that their densities are different.

(3) Dynamic equilibrium is the equivalence of the number of particles in vapour phase to the number of particles in liquid phase.

Those statements were presented to the participants in the original language of the study-Turkish. Hence, to make them more clear, they can be explained in more detail in the following way.

The first statement says that the protons which stay in the nucleus of the atom attract various electrons more intensely. Those more intensely attracted electrons are the ones which stay in the orbitals that are closer to the centre of the atom - nucleus. The outer electrons (which are away from the centre of the atom) are attracted less intensely by the protons. The expected correct student explanation for this statement is: protons attract all the electrons (both near and far away from the centre of the atom) with the same strength. However, all electrons do not experience the attraction of the protons at the same level. The reason for this situation is the effect of screening. Screening means the blockage of electrons' experience of protons' attraction due to other electrons that circulate between this electron and the centre of the atom. In screening, the electrons which remain between the outer electrons and the nucleus of the atom reduce the outer electrons' experience of attraction by the protons.

To describe the second statement in detail, it is indicated that when you mix two or more liquids with one another, they might stay in different layers. They do not mix with each other. All the liquids stay in their own layers, forming a heterogeneous structure. This occurs due to the fact that they have different densities. The expected students' explanation should be the following: the reason for two or more liquids not mixing with one another is related to chemical attractions. It is not related to the fact that their densities are different. Mixing with one another means that they dissolve in each other by forming a homogenous structure. Appropriate chemical attractions cause dissolution. On the other hand, if there is no chemical attraction, different liquids will not mix with one another. For example, polar substances dissolve in polar solutions ( $\mathrm{HCl}$ dissolves in $\mathrm{H}_{2} \mathrm{O}$ ), whereas non-polar substances dissolve in non-polar solutions $\left(\mathrm{CCl}_{4}\right.$ dissolves in $\left.\mathrm{C}_{6} \mathrm{H}_{6}\right)$. However, polar substances do not dissolve in nonpolar solutions $\left(\mathrm{H}_{2} \mathrm{O}\right.$ does not dissolve in $\left.\mathrm{C}_{6} \mathrm{H}_{6}\right)$.

The third statement says that the number of particles in vapour phase is equal to the number of particles in liquid phase during dynamic equilibrium. It highlights the equivalence of the particles in liquid and vapour phases. However, the expected answer should emphasize the transition of the phase of the substance from liquid to vapour and from vapour to liquid during dynamic equilibrium. During this process, the number of the particles which go through vapour phase from liquid phase and the number of the particles which go through liquid phase from vapour phase is equal. 
As can be seen, three statements related to different chemistry topics were included in the data gathering form. Those statements were selected among the topics covered in the first, fourth and eighth week. The first one was selected from the topic entitled Particulate nature of matter ( $1^{\text {st }}$ week's topic), the second one was selected from the topic entitled Solutions ( $8^{\text {th }}$ week's topic) and the third one was selected from the topic entitled States of matter ( $4^{\text {th }}$ week's topic). At the time of the pre-test, no instruction was provided. Hence, students answered all of those questions using their previous knowledge only. When the inter-test was implemented, the topic mentioned in the first statement had been covered a month before, whereas the third one had just been covered with the experimental group. However, the second statement had not been covered. On the other hand, the experimental group students were expected to gain a number of cognitive skills to engage in discussions on the topics and reflect those gains to respond to the second statement although its topic had not been covered. At the time of the post-test, all topics had been covered in the MISC classes and the posttest had been implemented with all of the participants at the end of the semester. In addition, a data gathering form was used with the participants as a delayed post-test 2 and a half years after the study had been conducted.

The participants were asked to state whether they agree or disagree with the statements and why. As can be seen, all of the statements indicate misconceptions. The fact that the students agree with the statement demonstrate that they possess misconceptions related to that topic, which is supported by their own statements. On the other hand, students who disagree with the statement could make a scientific explanation about the statement instead of accepting the misconception as the correct answer.

In addition, an evaluation form was prepared for the experimental group students with an open-ended question saying "Please evaluate the course in all aspects". They were asked to write their impressions of the course by considering the whole semester, without limiting the length and the content of their writing.

\section{Data Analyses}

Students' responses to each statement were analysed in terms of content analyses (Yıldırım \& Şimşek, 2008, p. 227) and were collected under 5 categories: correct, partial misconception, misconception, no response and irrelevant. The explanation of each of the categories follows. Correct - student responses correspond to scientific knowledge. Partial misconception - student responses are partially contradictory to scientific knowledge and partially correspond to scientific knowledge. Misconception student responses totally contradict scientific knowledge. Irrelevant - student responses mention other points instead of what is mentioned in the statement. No response - the cases which provide no explanation by the students. Examples for each category from the participants' responses were also included in the section on results.

Descriptive statistics was used to quantify data and to compare students' comprehension throughout different parts of the study (pre-test, inter-test, post- 
test and delayed post-test). In addition, Kruskal-Wallis $\mathrm{H}$ tests were implemented in order to see whether there was a significant difference between the control and the experimental group regarding each statement in the pre-test and post-test. Moreover, Wilcoxon signed-rank tests were implemented in order to see whether there was a significant difference between pre-test and post-test results of the participants in the same group for each statement. For this reason, a weighted scale was used in order to code data: 4 for correct, 3 for partial misconception, 2 for misconception, 1 for irrelevant and 0 for no response. The collected data was coded in an Excel file and then transferred to SPSS 16.0 program in order to conduct statistics tests. No comparison was made between the pre- and inter-test results, nor between pre- and delayed posttest results. The frequency-percentage distribution in the form of tables was found to be satisfactory enough to present the trend among the pre-, inter-, post- and delayed post-test results for experimental group students' conceptions.

Also, the experimental group students' opinions related to the MISC were evaluated with content analyses under proper themes and they were also quantified to determine their approaches to the course.

\section{Results}

\section{Participants' Comprehension}

Participants' comprehension related to the first statement - "Protons attract closer electrons more than the distant ones" is presented in Tables 1 and 2.

Table 1

Distribution of the participants' comprehension of the first statement

\begin{tabular}{|c|c|c|c|c|c|c|c|}
\hline \multirow{2}{*}{ Groups } & \multirow{2}{*}{ Tests } & Correct & $\begin{array}{c}\text { Partial } \\
\text { misconception }\end{array}$ & Misconception & No response & Irrelevant & Total \\
\hline & & \multicolumn{6}{|c|}{ Frequency [f] (Percentage [\%]) } \\
\hline \multirow{4}{*}{ Exp. } & Pre-test & $3(11.5)$ & $1(3.8)$ & $16(61.5)$ & $6(23.1)$ & $0(0)$ & $26(100.0)$ \\
\hline & Inter-Test & $26(100.0)$ & $0(0)$ & $0(0)$ & $0(0)$ & $0(0)$ & $26(100.0)$ \\
\hline & Post-Test & $24(92.3)$ & $0(0)$ & $2(7.7)$ & $0(0)$ & $0(0)$ & $26(100.0)$ \\
\hline & $\begin{array}{l}\text { Delayed } \\
\text { Post-test }\end{array}$ & $24(92.3)$ & $2(7.7)$ & $0(0)$ & $0(0)$ & $0(0)$ & $26(100.0)$ \\
\hline \multirow{2}{*}{ Control } & Pre-test & $5(19.2)$ & $2(7.7)$ & $14(53.8)$ & $3(11.5)$ & $2(7.7)$ & $26(100.0)$ \\
\hline & Post-Test & $4(15.4)$ & $2(7.7)$ & $18(69.2)$ & $0(0)$ & $2(7.7)$ & $26(100.0)$ \\
\hline
\end{tabular}

As can be seen from Table 1, pre-test results indicated that about $12 \%$ of the experimental group participants provided correct answers, whereas about $62 \%$ of them possessed misconceptions and about $23 \%$ of them could not provide any answer. Intertest results demonstrated a positive change in experimental group's responses. However, post-test results revealed misconceptions and delayed post-test results revealed partial misconceptions in experimental group participants' responses to this statement.

When the pre-test results of the control and experimental group related to the first statement were analysed with Kruskal-Wallis $\mathrm{H}$ test, no significant difference 
was determined between those two groups $x^{2}(1, N=52)=1.835, p=.176$. On the other hand, Kruskal-Wallis $\mathrm{H}$ test results indicated a significant difference between the experimental and control group for the post-test results $x^{2}(1, N=52)=6.015, p=.014$. Table 2

Wilcoxon signed-rank test statistics for pre-test and post-test results for the first statement

\begin{tabular}{|c|c|c|c|c|c|c|}
\hline Group & $\begin{array}{l}\text { Post - Pre } \\
\text { (Types of understanding) }\end{array}$ & $\mathrm{N}$ & Mean Rank & Sum of Ranks & $z$ & $\mathrm{p}$ \\
\hline \multirow{4}{*}{ Exp. } & Negative Change $^{\mathrm{a}}$ & 0 & .00 & .00 & $4.17^{*}$ & .0001 \\
\hline & Positive Change ${ }^{\mathrm{b}}$ & 21 & 11.00 & 231.00 & & \\
\hline & No Change ${ }^{c}$ & 5 & - & - & & \\
\hline & Total number of students & 26 & & & & \\
\hline \multirow{4}{*}{ Control } & Negative Change $^{\mathrm{a}}$ & 8 & 9.00 & 72.00 & $.212^{*}$ & .832 \\
\hline & Positive Change ${ }^{\mathrm{b}}$ & 8 & 8.00 & 64.00 & & \\
\hline & No Change & 10 & & & & \\
\hline & Total number of students & 26 & & & & \\
\hline
\end{tabular}

*Based on negative ranks. Note: a. post < pre; b. post > pre; c. post $=$ pre

According to Table 2, Wilcoxon signed-rank test analyses for the pre-test and posttest results of the experimental group showed an improvement in students' scientific responses due to the application of the CCD method $(\mathrm{z}=4.17, \mathrm{p}=.0001)$. However, no such improvement was identified in the control group's responses related to pre-test and post-test $(\mathrm{z}=0.212, \mathrm{p}=.832)$.

Participants' comprehension related to the second statement - "The reason for the several liquids not mixing with one another is the fact that their densities are different" is presented in Tables 3 and 4.

Table 3

Distribution of the participants' comprehensions of the second statement

\begin{tabular}{|c|c|c|c|c|c|c|c|}
\hline \multirow[t]{2}{*}{ Groups } & \multirow[t]{2}{*}{ Tests } & Correct & $\begin{array}{c}\text { Partial } \\
\text { misconception }\end{array}$ & Misconception & No response & Irrelevant & Total \\
\hline & & \multicolumn{6}{|c|}{$f(\%)$} \\
\hline \multirow{4}{*}{ Exp. } & Pre-test & $4(15.4)$ & $3(11.5)$ & $15(57.7)$ & $2(7.7)$ & $2(7.7)$ & $26(100.0)$ \\
\hline & Inter-Test & $13(50.0)$ & $2(7.7)$ & $9(34.6)$ & $2(7.7)$ & $0(0)$ & $26(100.0)$ \\
\hline & Post-Test & $17(65.4)$ & $3(11.5)$ & $6(23.1)$ & $0(0)$ & $0(0)$ & $26(100.0)$ \\
\hline & $\begin{array}{l}\text { Delayed } \\
\text { post-test }\end{array}$ & $19(73.1)$ & $1(3.8)$ & $6(23.1)$ & $0(0)$ & $0(0)$ & $26(100.0)$ \\
\hline \multirow{2}{*}{ Control } & Pre-test & $5(19.2)$ & $3(11.5)$ & $16(61.5)$ & $2(7.7)$ & $0(0)$ & $26(100.0)$ \\
\hline & Post -test & $9(34.6)$ & $2(7.7)$ & $15(57.7)$ & $0(0)$ & $0(0)$ & $26(100.0)$ \\
\hline
\end{tabular}

According to Table 3, more than a half of both the experimental (about 58\%) and control group students (62\%) possessed misconceptions related to the second statement in the pre-test. The inter-test results showed an improvement in the experimental group students' responses, which could be seen from an increase 
incorrect responses (50\%) and a decrease in misconceptions (35\%) when compared to pre-test results. In the final phase, post-test results indicated that the percentage of remaining misconceptions was 23 , while the percentage of correct responses was 65 for the experimental group students. The results of the delayed post-test were also similar to the results of the post-test for the experimental group participants.

When the two groups' comprehension in the pre-test was analysed with KruskalWallis $\mathrm{H}$ test, it was determined that there was no significant difference between them $x^{2}(1, N=52)=1.322, p=.250$. However, Kruskal-Wallis $\mathrm{H}$ test statistics revealed a significant difference between the control and experimental group's post-test results $x^{2}(1, N=52)=6.015, p=.014$.

Table 4

Wilcoxon signed-rank test statistics for pre-test and post-test results for the second statement

\begin{tabular}{|c|c|c|c|c|c|c|}
\hline Group & $\begin{array}{l}\text { Post - Pre } \\
\text { (Types of understanding) }\end{array}$ & $\mathrm{N}$ & Mean Rank & Sum of Ranks & z & $\mathrm{p}$ \\
\hline \multirow{4}{*}{ Exp. } & Negative Change ${ }^{\mathrm{a}}$ & 2 & 14.00 & 28.00 & $3.31 *$ & .001 \\
\hline & Positive Change $^{\mathrm{b}}$ & 20 & 11.25 & 225.00 & & \\
\hline & No Change ${ }^{c}$ & 4 & - & - & & \\
\hline & Total number of students & 26 & & & & \\
\hline \multirow{4}{*}{ Control } & Negative Change $^{\mathrm{a}}$ & 8 & 9.00 & 72.00 & $.212^{*}$ & .832 \\
\hline & Positive Change ${ }^{b}$ & 8 & 8.00 & 64.00 & & \\
\hline & No Change & 10 & & & & \\
\hline & Total number of students & 26 & & & & \\
\hline
\end{tabular}

*Based on negative ranks. Note: a. post < pre; b. post > pre; c. post = pre

As can be seen in Table 4, Wilcoxon signed-rank test statistics indicated an increase in the number of experimental group students' correct answers after the instruction $(\mathrm{z}=3.31, \mathrm{p}=.001)$. On the other hand, no such improvement was determined for the control group as a result of Wilcoxon signed-rank test $(\mathrm{z}=0.212, \mathrm{p}=.832)$.

Participants' comprehension related to the third statement - "Dynamic equilibrium is the equivalence of the number of particles in gas phase to the number of particles in liquid phase" is presented in Tables 5 and 6.

When Table 5 is examined, it is clear that there are remarkable differences among the percentages of correct responses and misconceptions from the pre-test to posttest results. The results indicated an improvement in the experimental group students' conceptualizations, whereas the consequences were reverse for the control group. On the other hand, delayed post-test results indicated that the experimental group participants still had opinions which included misconceptions.

Whereas Kruskal-Wallis $\mathrm{H}$ test statistics did not show a significant difference between the experiment and control group's responses related to pre-test $x^{2}(1, N=52)=$ $1.322, p=.250)$ in the first phase of the study, the post-test results indicated a significant difference between them $x^{2}(1, N=52)=23.415, p=.0001$ in the third phase. 
Table 5

Distribution of the participants' comprehension of the third statement

\begin{tabular}{llcccccc}
\hline \multirow{2}{*}{ Groups } & Tests & Correct & $\begin{array}{c}\text { Partial } \\
\text { misconception }\end{array}$ & Misconception & $\begin{array}{c}\text { No } \\
\text { response }\end{array}$ & Irrelevant & Total \\
\cline { 3 - 7 } & & \multicolumn{7}{c}{$\mathrm{f}(\%)$} \\
\hline \multirow{3}{*}{ Exp. } & Pre-test & $3(11.5)$ & $1(3.8)$ & $19(73.1)$ & $3(11.5)$ & $0(0)$ & $26(100.0)$ \\
& Inter-Test & $13(50.0)$ & $0(0)$ & $10(38.5)$ & $3(11.5)$ & $0(0)$ & $26(100.0)$ \\
& Post-Test & $23(88.5)$ & $0(0)$ & $1(3.8)$ & $2(7.7)$ & $0(0)$ & $26(100.0)$ \\
& Delayed & $22(84.6)$ & $0(0)$ & $4(15.4)$ & $0(0)$ & $0(0)$ & $26(100.0)$ \\
& post-test & & & & & & \\
\multirow{2}{*}{ Control } & Pre-test & $7(26.9)$ & $0(0)$ & $7(26.9)$ & $10(38.5)$ & $2(7.7)$ & $26(100.0)$ \\
& Post-test & $1(3.8)$ & $3(11.5)$ & $12(46.2)$ & $6(23.1)$ & $4(15.4)$ & $26(100.0)$ \\
\hline
\end{tabular}

Table 6

Wilcoxon signed-rank test statistics for pre-test and post test results for the third statement

\begin{tabular}{llccccc}
\hline Group & $\begin{array}{l}\text { Post - Pre } \\
\text { (Types of understanding) }\end{array}$ & $\mathrm{N}$ & Mean Rank & Sum of Ranks & $\mathrm{z}$ & $\mathrm{p}$ \\
\hline \multirow{4}{*}{ Exp. } & Negative Change $^{\mathrm{a}}$ & 1 & 1.50 & 1.50 & $4.72^{*}$ & .0001 \\
& Positive Change $^{\mathrm{b}}$ & 19 & 10.97 & 208.50 & & \\
& No Change $^{\mathrm{c}}$ & 6 & - & - & & \\
& Total number of students & 26 & & & & \\
& Negative Change $^{\mathrm{a}}$ & 11 & 11.77 & 129.50 & $.099^{*}$ & .921 \\
Control & Positive Change $^{\mathrm{b}}$ & 11 & 11.23 & 123.50 & & \\
& No Change $^{c}$ & 4 & & & & \\
& Total number of students & 26 & & & & \\
\hline
\end{tabular}

*Based on negative ranks. Note: a. post < pre; b. post $>$ pre; c. post $=$ pre

Table 6 shows that Wilcoxon signed-rank test statistics revealed a significant difference among experimental group responses for the pre-test and post-test results, as in the previous ones, which proved the positive effect of CCD method on students' correct answers $(\mathrm{z}=4.72 ; \mathrm{p}=.0001)$. However, no such difference was determined among the control group responses for the pre-test and post-test results $(\mathrm{z}=.099$; $\mathrm{p}=.921)$.

Table 7 provides examples of students' opinions to illustrate each category used in the analysis of the statements.

Table 7

Examples from participants' opinions

\begin{tabular}{|c|c|c|}
\hline $\begin{array}{l}\text { Question } \\
\quad \text { No }\end{array}$ & Category & Students' Opinions \\
\hline \multirow{3}{*}{1} & Correct & $\begin{array}{l}\text { The same attraction is applied to each electron. However, each electron } \\
\text { experiences that attraction differently. }\end{array}$ \\
\hline & Partial Misconception & $\begin{array}{l}\text { The attraction ability of proton decreases with screening when } \\
\text { electrons are placed. }\end{array}$ \\
\hline & Misconception & Closer electrons are attracted by protons more than the distant ones. \\
\hline
\end{tabular}


I know that electrons do not fall onto the nucleus due to their speed. The reason why they do not fall despite protons' attraction is the fact

$1 \quad$ Irrelevant that closer ones are attracted more since " + " attracts "-.". F= $\mathrm{q}_{1} \mathrm{q}_{2} / \mathrm{d}^{2}(\mathrm{~F}$ decreases as $d$ decreases.)

\begin{tabular}{ll}
\hline Correct & $\begin{array}{l}\text { Liquids do not mix due to their polarity. This is also related to the } \\
\text { solubility. For instance, despite the fact that densities of water and } \\
\text { alcohol are different, they dissolve in each other, because each of them } \\
\text { is polar. }\end{array}$ \\
The reason why several liquids do not mix with one another might \\
be related to density difference. However, that is not the only reason. \\
Polarity also has effect on that. \\
When there is density difference, a more dense liquid goes to the \\
bottom and the less dense one stays on it and they do not mix with \\
each other. \\
The concentrations of the liquids are different from each other. Hence \\
they do not mix with each other.
\end{tabular}

\section{Experimental Group Participants' Opinions on MISC}

Table 8

Experimental group's opinions on MISC

\begin{tabular}{lcc}
\hline Theme & $f$ & $\%$ \\
\hline It helped me face and remove my misconceptions. & 18 & 28.6 \\
The implementation of the course was so effective and efficient. & 14 & 22.2 \\
It is an essential and beneficial course. & 6 & 9.5 \\
It should be a mandatory course to be taken by everyone. & 6 & 9.5 \\
It should be given in other (physics and biology) branches as well. & 5 & 7.9 \\
I am very pleased to have taken that course. & 4 & 6.3 \\
It should be given in earlier semesters. & 3 & 4.8 \\
It increased my self-confidence. & 3 & 4.8 \\
I will use the same method while teaching. & 2 & 3.2 \\
The topics covered in the course should be limited with elementary level. & 2 & 3.2 \\
Total & 63 & 100.00 \\
\hline
\end{tabular}

When the participants in the experimental group were asked to evaluate MISC in all aspects, the opinions demonstrated in Table 8 were collected. Since one student could 
write about more than one theme in his/her paper, the total frequency of the themes is higher than the total number of experimental group students.

Most of the opinions of the experimental group students were found to be positive, as can be summarized in Table 8. The related participants expressed the opinion that the course removed their misconceptions by making them face these misconceptions. Also, they claimed that the method of the course added a different point of view and the course was completed efficiently. The students were glad to have taken the course and indicated that they could utilize the same method in their own future work in the classroom. These findings show that the course has reached its objectives.

\section{Discussion and Conclusions}

The results of the study can be summarized under two headings-as cognitive and affective results. Accordingly, in terms of cognitive results, it is clear that the percentage of correct responses increases and most misconceptions are eliminated with the help of the CCD method. This result shows parallelism with Eryllmaz's study which showed its efficiency in the elimination of misconceptions related to force and motion (2002). Also, pre-test results revealed irrelevant responses for the second question. This result is similar to the previous study results obtained by Güneş et al. (2010). However, posttest results demonstrate that such responses do not appear in the end of study.

The reason why an inter-test was conducted in this study is because the topics related to the first question were covered. However, the topic related to the second statement was not covered and the third one had been only recently covered at the time of the inter-test administration. For this reason, an inter-analysis was conducted in order to check how students' conceptions changed in relation to the covered topics. Also, we intended to observe whether students could apply their inquiry skills to the topic which has not been covered yet although the evaluation period is shorter. Post-test administration allowed the researchers to make the whole evaluation of the efficiency of the CCD method.

As reported in Tables 1, 3 and 5, the percentage of correct responses to all three questions increased from the pre-test to post-test results in the end of the semester in the experimental group. This result indicates the elimination of misconceptions in high percentages. Also, it is supported by the decrease in the number of partial misconceptions of those students. No such improvement in the control group students' comprehension was detected at the end of the semester. More than a half of the control group participants were found to have misconceptions both in the pre-test and posttest results for the first and second statements. High percentages of misconceptions and relatively low percentages of correct responses depict the need of conceptual change for the control group participants.

When the results of the delayed post-test are considered, it can be seen that several participants in the experimental group have misconceptions despite the fact that they have had work experience as in-service science teachers. This outcome is an indication 
that their misconceptions are highly robust (Viennot, 1979, p. 205; as cited in Posner et al., 1982). Misconceptions might reappear in individuals' minds in time.

In this study, it has been seen that the misconceptions related to the second question are more resistant to change than the others. This may be due to the fact that the statement involves more than one topic (solutions, mixtures, bonds, matter). Therefore, it requires students to consider different topics together, for which metacognitive skills are needed. In addition, as presented in the frequency-percentage distributions, a decrease in the categories No response and Irrelevant is significant. It shows that students who take MISC construct opinions at the end of semester for the questions which received no response or irrelevant responses in the pre-test.

The extensive evaluation by the experimental group participants at the final stage exhibits the affective results of the study by proving the efficacy of the method along with their positive opinions. Responses showing an increase in self-confidence, effective course instruction, insights for future classrooms and pleasure to have taken that course are all affirmative in that aspect. Those students gained different points of view while searching for articles about course topics.

Those findings could be presented as solutions to the problems identified in the studies of Halim and Meerah (2002), Kahyaoğlu and Yavuzer (2004), Karamustafaoğlu (2009) and Canbazoğlu, Demirelli and Kavak (2010).

In the light of the study findings, the following recommendations might contribute to the concept teaching in science education:

(i) CCD method can be utilized in the removal of misconceptions.

(ii) Physics and biology topics can be added to the course content by increasing the course credit or separate courses can be conducted for biology and physics topics as well.

(iii) That course might be a mandatory course rather than an elective course in education faculties.

(iv) The course can be conducted over the $5^{\text {th }}$ and $6^{\text {th }}$ semesters in the programmes which last 4 years, or it can be conducted over the $7^{\text {th }}$ and $8^{\text {th }}$ semesters in the programmes which last 5 years, in order to meet teacher candidates' needs.

\section{Limitations}

Semi-structured interviews might be conducted with the experimental group participants during the second phase of the study in order to determine whether the CCD method provided a positive effect on the students' responses in the inter-test, especially for the topic which had not been covered in the class. Thus, the inter-test results could be more functional. 


\section{References}

Ağgül Yalçın, F. (2011). Fen bilgisi öğretmen adaylarının asit baz konusunda sahip oldukları kavram yanılgılarının sınıf düzeyine göre değişiminin incelenmesi [Examination of science teacher candidates' misconceptions regarding acids-bases subject according to their grade levels]. Türk Fen Eğitimi Dergisi [Journal of Turkish Science Education], 8(3), 161-172.

Akgün, A., Gönen, S., \& Yılmaz, A. (2005). Fen bilgisi öğretmen adaylarının karışımların yapısı ve iletkenliği konusundaki kavram yanılgıları [Misconceptions of preservice science teachers regarding the structure and conductivity of mixtures]. Hacettepe Universitesi Eğitim Fakültesi Dergisi [Hacettepe University Journal of Education], 28, 1-8.

Ayvacı, H. Ş., \& Çoruhlu, T. Ş. (2009). Fiziksel ve kimyasal değişim konularındaki kavram yanılgılarının düzeltilmesinde açıklayıcı hikâye yönteminin etkisi [Effects of explanatory stories on elimination of students' misconceptions about physical and chemical change]. Ondokuz Mayıs Üniversitesi Eğitim Fakültesi Dergisi [Ondokuz Mayıs University Journal of Education Faculty], 28, 93-104.

Azizoğlu, N., \& Alkan, M. (2002). Kimya öğretmenliği lisans öğrencilerinin faz dengeleri konusundaki kavram yanılgılar1 [Misconceptions of chemistry teaching undergraduate students on phase equilibria]. V. National Science and Mathematics Education Congress, September 16-18, Ankara, Turkey.

Büyüköztürk, Ş., Çakmak, E. K., Akgün, Ö. E., Karadeniz, Ş., \& Demirel, F. (2010). Bilimsel Araştırma Yöntemleri [Scientific Research Methods]. Ankara: PegemA.

Canbazoğlu, S., Demirelli, H., \& Kavak, N. (2010). Fen bilgisi öğretmen adaylarının maddenin tanecikli yapısı ünitesine ait konu alan bilgileri ile pedagojik alan bilgileri arasındaki ilişkinin incelenmesi [Investigation of the relationship between pre-service science teachers' subject matter knowledge and pedagogical content knowledge regarding the particulate nature of matter]. Illkögrretim Online [Elementary Online], 9(1), 275-291.

Duit, R., \& Treagust, D. F. (2003). Conceptual change: A powerful framework for improving science teaching and learning. International Journal of Science Education, 25(6), 671 - 688. http://dx.doi.org/10.1080/09500690305016

Eryilmaz, A. (2002). Effects of conceptual assignments and conceptual change discussions on students' misconceptions and achievement regarding force and motion. Journal of Research in Science Teaching, 39(10), 1001-1015. http://dx.doi.org/10.1002/tea.10054

Güneş, T., Dilek, N. Ş., Demir, E. S., Hoplan, M., \& Çelikoğlu, M. (2010). Öğretmenlerin kavram öğretimi, kavram yanılgılarını saptama ve giderme çalışmaları üzerine nitel bir araştırma [Qualitative research on the efforts of teachers about the concept teaching, determination and elimination of the misconceptions]. Proceedings of the International Conference on New Trends in Education and Their Implications. Antalya, Turkey, 936 - 944.

Halim, L., \& Meerah, S. M. (2002). Science trainee teachers' pedagogical content knowledge and its influence on physics teaching. Research in Science \& Technological Education, 20(2), 215-225. http://dx.doi.org/10.1080/0263514022000030462

Hewson, M. G., \& Hewson, P.W. (1983). Effect of instruction using students' prior knowledge and conceptual change strategies on science learning. Journal of Research in Science Teaching, 20(8), 731-743. http://dx.doi.org/10.1002/tea.3660200804 
Kahraman, S., \& Demir, Y. (2001). Bilgisayar destekli 3 d öğretim materyallerinin kavram yanılgıları üzerindeki etkisi: atomun yapısı ve orbitaller [The effects of computer-based 3D instruction materials on misconceptions: atomic structure and orbitals]. Erzincan Eğitim Fakültesi Dergisi [Journal of Erzincan Education Faculty], 13(1), 173-188.

Kahyaoğlu, H., \& Yavuzer, Y. (2004). Öğretmen adaylarının ilköğretim 5. sınıf fen bilgisi dersindeki ünitelere ilişkin bilgi düzeyleri [The level of knowledge of pre-service teachers related to units used in science lessons given to the $5^{\text {th }}$ grade elementary school students]. İlkögretim Online [Elementary Online], 3(2), 26-34.

Kalın, B., \& Arıkıl, G. (2010). Çözeltiler konusunda üniversite öğrencilerinin sahip olduğu kavram yanilgilar1 [Misconceptions of undergraduate students about the topic "solutions"]. Necatibey Eğitim Fakültesi Elektronik Fen ve Matematik Eğitimi Dergisi [Necatibey Faculty of Education Electronic Journal of Science and Mathematics Education], 4(2), 177-206.

Karaer, H. (2007). Sınıf öğretmeni adaylarının madde konusundaki bazı kavramların anlaşılma düzeyleri ile kavram yanılgılarının belirlenmesi ve bazı değişkenler açısından incelenmesi [Examination of student teachers' levels of understanding and misconceptions of some concepts about substance and determination regarding some variables]. Kastamonu Eğitim Dergisi [Journal of Kastamonu Education], 15(1), 199-210.

Karamustafaoğlu, S., Ayas, A., \& Coştu, B. (2002). Sınıf öğretmeni adaylarının çözeltiler konusundaki kavram yanılgıları ve bu yanılgıların kavram haritası tekniği ile giderilmesi [Misconceptions of classroom teacher candidates related to the topic solutions and elimination of those misconceptions with concept mapping technique]. V. National Science and Mathematics Education Congress, September 16 - 18, Ankara, Turkey.

Karamustafaoğlu, O. (2009). Fen ve teknoloji eğitiminde temel yönelimler [Main trends on science and technology education]. Kastamonu Eğitim Dergisi [Journal of Kastamonu Education], 17(1), 87-102.

Nakiboğlu, C., \& Arık, R. Ö. (2006). 4. sınıf öğrencilerinin "gazlar” ile ilgili kavram yanılgilarının v-diyagramı kullanılarak belirlenmesi [Determination of $4^{\text {th }}$ grade students' misconceptions related to "gases" via v-diagrams]. Yeditepe Üniversitesi Eğitim Fakültesi Dergisi EDU7 [Yeditepe University Journal of Education Faculty EDU7], 1(2), 1-17.

Nussbaum, J., \& Novick, S. (1982). Alternative frameworks, conceptual conflict and accommodation: toward a principled teaching strategy. Instructional Science, 11, 183 200. http://dx.doi.org/10.1007/BF00414279

Online MEB (Ministry of Turkish Education) (2012). Accessed on 17 March 2012 at www. kocaeli.meb.gov.tr/bolumler/projeler/ogf/ana/sunu/aoyvstp.ppt

Posner, G.J., Strike, K.A., Hewson, P.W., \& Gertzog, W.A. (1982). Accommodation of a scientific conception: toward a theory of conceptual change. Science Education, 66(2), 211-227. http://dx.doi.org/10.1002/sce.3730660207

Saka, A., \& Akdeniz, A. R. (2006). Genetik konusunda bilgisayar destekli materyal geliştirilmesi ve 5e modeline göre uygulanması [The development of computer based material about genetics and its according to 5e model]. The Turkish Online Journal of Educational Technology - TOJET, 5(1), 129-141.

Sinan, O. (2009). Öğretmen adaylarının kimya ve biyoloji derslerinde kullanılan bazı ortak kavramları tanımlamalarındaki farklılıklar [Differences in prospective science teachers' descriptions of the same concepts used in chemistry and biology classes]. Faculty of 
Necatibey Education Electronic Journal of Science and Mathematics Education, 3(2), 1-21.

Taşdemir, A., \& Sarıkaya, M. (2005). Fen bilgisi öğretmen adaylarının çözeltiler kimyasını öğrenmelerine işbirlikli öğrenme yönteminin etkilerinin araştırılması [Research on the effects of cooperative learning on prospectıve science teachers' learning of solution chemistry]. Gazi Üniversitesi Kırşehir Eğitim Fakültesi Dergisi [Gazi University Journal of Kırşehir Education Faculty], 6(2), 197-207.

Tezcan, H., \& Salmaz, Ç. (2005). Atomun yapısının kavratılmasında ve yanlış kavramaların giderilmesinde bütünleştirici ve geleneksel öğretim yöntemlerinin etkileri [Effects of the traditional method and constructivist approach on the understanding of atomic structure and elimination of related misconceptions]. GÜ, Gazi Ĕ̆itim Fakültesi Dergisi [GU, Journal of Gazi Education Faculty], 25(1), 41-54.

Tao, P. K., \& Gunstone, R. F. (1999). The process of conceptual change in force and motion during computer-supported physics instruction. Journal of Research in Science Teaching, 36(7), 859-882. http://dx.doi.org/10.1002/(SICI)1098-2736(199909)36:7<859::AIDTEA7>3.0.CO;2-J

Vosniadou, S. (2007). Conceptual change and education. Human Development, 50, 47-54. http://dx.doi.org/10.1159/000097684

Yıldırım, A., \& Şimşek, H. (2008). Sosyal Bilimlerde Nitel Araştırma Yöntemleri [Qualitative Research Methods in Social Studies]. Ankara: Seçkin.

Zoller, U. (1990). Students' misunderstandings and misconceptions in freshman chemistry (general and organic). Journal of Research in Science Teaching, 27(10), 1053-1065. http:// dx.doi.org/10.1002/tea.3660271011

\section{Gamze Dolu}

Elementary Science Education Department, Necatibey Education Faculty, Balıkesir University DinkçilerMah., Soma Cad., 10100, Balıkesir, Turkey agamze@balikesir.edu.tr

\section{Handan Ürek}

Elementary Science Education Department, Necatibey Education Faculty, Balıkesir University DinkçilerMah., Soma Cad., 10100, Balıkesir, Turkey handanurek@balikesir.edu.tr 


\section{Prepoznavanje i eliminacija nekih pogrešnih predodžbi koje imaju studenti u kolegiju Pogrešne predodžbe u prirodnim znanostima}

\section{Sažetak}

Ovo istraživanje temelji se na prepoznavanju i eliminaciji nekih pogrešnih predodžbi studenata o području kemije. Zbog toga je primijenjen i proveden dizajn s predtestom i posttestom na statičnoj skupini na uzorku od 52 buduća nastavnika. Što se tiče sadržaja istraživanja, ispitanici u eksperimentalnoj skupini odabrali su kolegij Pogrešne predodžbe u prirodnim znanostima, a ispitanici u kontrolnoj skupini odabrali su kolegij Fizika u okolini kao svoj izborni kolegij. Za vrijeme istraživanja podaci su prikupljeni s pomoću obrasca koji se sastojao od 3 tvrdnje otvorenog tipa. Osim toga, pripremljen je evaluacijski obrazac da bi se ispitalo mišljenje sudionika u eksperimentalnoj skupini o kolegiju. Rezultat istraživanja dobiven je analizom predtesta s pomoću koje se prepoznalo nekoliko pogrešnih predodžbi koje su imali svi sudionici, a rezultati posttesta pokazali su da je kolegij Pogrešne predodžbe u prirodnim znanostima bio učinkovit pri eliminaciji pogrešnih predodžbi sudionika u eksperimentalnoj skupini. Također se pokazalo da je kolegij potreban i učinkovit. Rezultati posttesta koji je proveden s vremenskim odmakom potvrdili su ukorijenjenost pogrešnih predodžbi kod sudionika u eksperimentalnoj skupini, iako su oni već obavljali svoj posao nastavnika predmeta prirodnih znanosti.

Ključne riječi: kemija; rasprava o konceptualnoj promjeni.

\section{Uvod}

Budući da teme iz područja opće kemije pružaju osnovu za učenje kemije i raznih drugih tema vezanih uz područje fizike i biologije na sveučilišnoj razini obrazovanja, studenti bi trebali imati ispravne predodžbe o tom području. Međutim, Zoller tvrdi da se kemija na prvoj godini studija već tradicionalno smatra jednim od najproblematičnijih znanstvenih disciplina zbog teškoća u učenju, pogrešnih predodžbi i krivog shvaćanja (1990). Osim toga, teme iz kemije imaju brojne zajedničke 
termine s fizikom i/ili biologijom. Stoga bi se značenja tih zajedničkih pojmova trebala konceptualizirati i prenijeti studentima točno, da bi oni na ispravan način mogli stvarati veze među njima (Sinan, 2009). Međutim, studenti bi u svojim umovima mogli stvarati znanstvene spoznaje koje su njima specifične i logične, no koje su otporne na promjene, te se stoga stvaraju alternativne predodžbe. Te alternativne predodžbe mogu biti kontradiktorne znanstvenim spoznajama potpuno, djelomično ili ne moraju uopće imati veze sa znanstvenim spoznajama.

Proučavanjem literature može se vidjeti da postoje brojne studije koje se bave prepoznavanjem pogrešnih predodžbi studenata, a koje su vezane uz teme iz područja kemije (Azizoğlu i Alkan, 2002; Karamustafaoğlu, Ayas i Coştu, 2002; Akgün, Gönen i Yllmaz, 2005; Nakiboğlu i Arık, 2006; Karaer, 2007; Kalın i Arıkıl, 2010; Ağgül Yalçın, 2011). Spomenute se studije temelje na procesu prepoznavanja pogrešnih predodžbi koje imaju sveučilišni studenti, budući nastavnici. Sva provedena istraživanja pokazala su da znatan broj studenata dodiplomskih studija ima nekoliko pogrešnih predodžbi. Međutim, naglasak nije na prepoznavanju alternativnih predodžbi (Tao i Gunstone, 1999), nego je naglašeno razumijevanje procesa konceptualne promjene.

Konceptualna promjena može se definirati kao sposobnost restrukturiranja predznanja studenata koje se temelji na svakodnevnom iskustvu i laičkoj kulturi (Vosniadou, 2007). Postoje neophodni uvjeti koji vode do konceptualne promjene kod studenata, kao što su nezadovoljstvo, razumljivost, vjerojatnost i korisnost (Posner, Strike, Hewson i Gertzog, 1982). Kao što su naveli Hewson i Hewson, u ovom procesu se ne radi o pružanju novih informacija studentima, nego se radi o interakciji novog znanja s postojećim znanjem (1983). Razni autori najčešće analiziraju konceptualnu promjenu na dva načina: ili kao (1) restrukturiranje slabog znanja, asimilaciju ili konceptualno pohranjivanje ili (2) restrukturiranje čvrstog/radikalnog znanja, prilagodbu ili konceptualnu razmjenu tako što se tom procesu dodaje ili ne dodaje neizvjesnost jednostavnog povećanja znanja (Duit i Treagust, 2003). Također se raspravljalo i o epistemološkim, klasičnim i alternativnim aspektima (Duit i Treagust, 2003).

Kada se razmotri učinak različitih metoda na konceptualnu promjenu, može se uočiti da su sljedeće metode učinkovite pri eliminiranju pogrešnih predodžbi: digitalni 3D nastavni materijali (Kahraman i Demir, 2011), digitalni materijali i 5E model (Saka i Akdeniz, 2006), pojednostavljene priče (Ayvacı i Çoruhlu, 2009), integrativne nastavne metode (Tezcan i Salmaz, 2005), umne mape (Karamustafaoğlu, Ayas i Coştu, 2002) i suradničko učenje (Taşdemir i Sarıkaya, 2005). Uočeno je da su se među tim metodama proturječni događaji (koji mogu biti demonstracije ili fenomeni) pokazali vrlo uspješnima pri postizanju konceptualne promjene kod studenata, jer su oni u suprotnosti s njihovim postojećim znanjem o tim procesima (Tao i Gunstone, 1999).

Usprkos činjenici da su nastavnici jedan od glavnih elemenata koji upravljaju procesom učenja, $u$ istraživanju su otkriveni i različiti problematični slučajevi povezani s nastavnicima predmeta prirodnih znanosti i budućim nastavnicima predmeta 
prirodnih znanosit. Ta problematična područja obuhvaćaju nedostatak znanja ili nepotpuno poznavanje sadržaja (Kahyaoğlu i Yavuzer, 2004; Canbazoğlu, Demirelli i Kavak, 2010) i propuste u konceptualnoj nastavi (Halim i Meerah, 2002; Güneş, Dilek, Demir, Hoplan i Çelikoğlu, 2010). Karamustafaoğluovo proučavanje literature pokazalo je da se veći naglasak stavljao na teorijski rad nego na praktičan i primijenjen rad, te je on istaknuo važnost uvođenja prakse i primjene teorijskog znanja u akademsko područje i seminare da bi se postigao akademski napredak nastavnika predmeta prirodnih znanosti (2009).

Kada se uzmu u obzir te spoznaje spomenute u literaturi, može se primijetiti da postoje brojna ograničenja u konceptualnoj nastavi u sveučilišnoj izobrazbi nastavnika predmeta prirodnih znanosti. Vjerujemo da učinkovitost metoda koje se koriste u izobrazbi budućih nastavnika može dovesti do njihove konceptualizacije, a istodobno im biti i inspiracija u budućoj nastavničkoj karijeri. Stoga ovo istraživanje nema za cilj samo prepoznati nekoliko pogrešnih predodžbi koje sudionici imaju, nego i demonstrirati učinkovitost metode koja se zove metoda rasprave s ciljem postizanja konceptualne promjene (engl. CCD method) u eliminiranju tih pogrešnih predodžbi. Zbog toga će se praktični rad spominjati u vezi s konceptualnom nastavom, što će doprinijeti tome da budući nastavnici postanu iskusniji i dobro informirani. Također je u literaturi uočeno da postoji manji broj istraživanja koja su provedena korištenjem metode rasprave s ciljem postizanja konceptualne promjene. Osim toga, očekuje se da će kategorije koje se koriste u analizama podataka biti od koristi u sličnim istraživanjima. Stoga to istraživanje ima za cilj i dati znatan doprinos obrazovanju nastavnika predmeta prirodnih znanosti. Ciljevi istraživanja su: (i) prepoznati pogrešne predodžbe koje sudionici imaju o različitim temama iz područja kemije; (ii) provesti metodu rasprave s ciljem postizanja konceptualne promjene; (iii) odrediti učinak metode rasprave s ciljem postizanja konceptualne promjene na studente koji su odabrali kolegij Pogrešne predodžbe u prirodnim znanostima i (iv) testirati ukorijenjenost pogrešnih predodžbi. Postavljena su sljedeća pitanja u istraživanju: Koje pogrešne predodžbe imaju sudionici vezane uz (a) privlačnu silu između protona i elektrona, (b) nemiješanje nekoliko tekućina različitih gustoća, (c) dinamičku ravnotežu?

\section{Metode}

\section{Sudionici}

U ovom istraživanju sudjelovala su 52 studenta treće i četvrte godine na Učiteljskom fakultetu - Odsjeku za obrazovanje nastavnika predmeta Osnova prirodnih znanosti, a koje je jedno od državnih sveučilišta u zapadnoj Turskoj. Četrdeset je sudionika bilo ženskog spola, a dvanaest muškog spola. Program obrazovanja nastavnika predmeta osnova prirodnih znanosti je četverogodišnji dodiplomski studij u Turskoj, a prema kurikulu ti studenti moraju odabrati 4 izborna kolegija tijekom svojeg fakultetskog obrazovanja. Jedan od tih izbornih kolegija sluša se na drugoj godini, a preostala se 
tri kolegija odabiru na četvrtoj godini. Ako je prosjek ocjena studenta zadovoljavajuć, ta tri izborna kolegija mogu se također odabrati i ranije, na trećoj godini. U ovom istraživanju 30 sudionika bili su studenti na trećoj godini studija, a još ih je 22 bilo na završnoj godini studija. Uzorak ispitanika dobiven je metodom namjernog uzorka (Büyüköztürk, Çakmak, Akgün, Karadeniz i Demirel, 2010, str. 89).

\section{Postupak}

Primijenjen je dizajn predtesta i posttesta na statičnoj skupini, koji pripada području eksperimentalnog dizajna u istraživanju, da bi se dobio odgovor na pitanja postavljena u istraživanju (Büyüköztürk, Çakmak, Akgün, Karadeniz i Demirel, 2010, str. 200). U ovom je istraživanju polovina ispitanika $(n=26)$ pripadala eksperimentalnoj skupini. Ti su studenti odabrali kolegij Pogrešne predodžbe u prirodnim znanostima kao svoj izborni kolegij, a druga je polovina ispitanika $(n=26)$ činila kontrolnu skupinu. Oni su odabrali drugi izborni kolegij - Fizika u okolini, koji se mogao slušati u isto vrijeme. Istraživanje se temelji na ispitivanju učinka metode rasprave s ciljem postizanja konceptualne promjene, a koja se primjenjivala tijekom jednog semestra u kojem se održavao kolegij Pogrešne predodžbe u prirodnim znanostima. Na početku semestra studenti u eksperimentalnoj skupini dobili su teme za svaki tjedan. O njima su morali potražiti članke i prije dolaska na nastavu provesti potrebna istraživanja. Teme uključene u to istraživanje bile su: (i) Čestična svojstva tvari, (ii) Otopine, (iii) Stanja tvari.

Tijekom tog semestra studenti su rješavali test na početku nastave, a test se sastojao od znanstveno točnih i netočnih tvrdnji. Nakon rješavanja, studenti su međusobno razmijenili svoje testove. Na nastavi se razgovaralo o njihovim odgovorima i razlozima zbog kojih su dali takve odgovore, uzimajući u obzir razne aspekte i uz vodstvo nastavnika koji je predavao taj kolegij. Nakon toga je nastavnik predstavio znanstvena objašnjenja, pa su studenti izrazili svoje mišljenje i svoje komentare. Na početku su studenti bili nezadovoljni svojim netočnim odgovorima, no nakon toga su stekli razumljivo, vjerodostojno i korisno znanje. Tijekom tog procesa studenti su različitim bojama označili točne i netočne odgovore da bi provjerili konceptualizaciju svojih kolega prije nastave. Predavanje je završilo raspravom o popisu literature koja studentima može biti od koristi kada budu pretraživali teme iz različitih članaka. Međutim, studenti u kontrolnoj skupini nisu imali takvu nastavu. Umjesto toga je nastava u njihovu kolegiju, Fizika u okolini, kroz cijeli semestar bila usmjerena na interpretaciju osnovnih pojmova fizike s kojima se studenti susreću u svakodnevnom životu.

$\mathrm{Na}$ temelju takve perspektive istraživanje je bilo provedeno u tri dijela.

\section{Prvi dio istraživanja}

Da bi se utvrdile trenutne pretpostavke koje studenti imaju, svim sudionicima podijeljeni su obrasci za prikupljanje podataka. Svaki se obrazac sastojao od 3 tvrdnje, a studentima su podijeljeni u obliku predtesta na početku semestra, prije provođenja nastave iz kolegija Pogrešne predodžbe u prirodnim znanostima i Fizika u okolini. 


\section{Drugi dio istraživanja}

Nakon provođenja predtesta, istraživači su izvodili nastavu iz kolegija Pogrešne predodžbe u prirodnim znanostima sa studentima u eksperimentalnoj skupini, koristeći se metodom rasprave s ciljem postizanja konceptualne promjene. Tom su se metodom već prije koristili Nussbaum i Novick (1982) pri eliminiranju pogrešnih predodžbi koje su studenti imali o čestičnoj strukturi plinova. $U$ daljnjem tekstu navedene su faze metode rasprave s ciljem postizanja konceptualne promjene (online MEB, 2012). Ona pomaže studentima: (i) da budu svjesni svojih ranijih predodžbi, (ii) da objasne $\mathrm{i}$ ispitaju pojmove ili hipoteze, (iii) da se snađu u situacijama koje ne mogu objasniti koristeći se svojim predznanjem, (iv) da budu svjesni proturječnosti uz pomoć nekog proturječnog događaja, (v) da grade znanje s pomoću međusobnog djelovanja ili prikazanih informacija, (vi) da shvate da su novi pojmovi snažniji od starih, (vii) da osjete da se mentalno razvijaju i napreduju, (viii) da imaju vjeru u sebe i svoje sposobnosti, (ix) da kontroliraju razumijevanje znanosti s konceptualnog aspekta. Uz to, ta metoda studentima pomaže da razviju vještine propitivanja. Kao što se može zaključiti iz navedenih faza, potiče se i kognitivni i afektivni razvoj studenata.

Kolegij Pogrešne predodžbe u prirodnim znanostima zahtijevao je od studenata da provedu kratko istraživanje o temi zadanoj za taj dan i da na nastavu donesu članke. Tijekom kolegija studenti su rješavali test $\mathrm{s}$ ciljem utvrđivanja njihovih pogrešnih predodžbi o temi zadanoj na početku. Nakon toga su se kao primjeri čitali nijhovi odgovori, pa je uslijedila rasprava o tome jesi li ti odgovori točni ili netočni, uz primjenu metode rasprave s ciljem postizanja konceptualne promjene. Tako su se studenti mogli suočiti sa svojim pogrešnim predodžbama. K tomu, nastavnici su održali prezentaciju da bi pomogli studentima u izgradnji znanja. Na kraju kolegija sažeti su svi članci koje su studenti donijeli, da bi se njhovo znanje moglo usustaviti i proširiti. Isti obrazac za prikupljanje podataka primijenjen je kod studenata u 5. tjednu nastave, da bi se s pomoću međutesta provela analiza kolegija. Zadatak koji su studenti imali bio je isti kao i u predtestu. Do trenutka provedbe međutesta dvije od tri teme koje su studenti istraživali bile su obrađene na nastavi. Razlog provođenja međutesta bio je utvrditi je li došlo do kakvog napretka u predodžbama koje studenti imaju, u usporedbi s rezultatima predtesta.

\section{Treći dio istraživanja}

Na kraju semestra, kao posttest, primijenjen je obrazac za prikupljanje podataka od svih studenata, i u kontrolnoj i u eksperimentalnoj skupini. Očekivalo se da će se s pomoću rezultata posttesta pokazati učinkovitost kolegija Pogrešne predodžbe u prirodnim znanostima, kada se usporede dvije skupine. Također, studenti u eksperimentalnoj skupini zamoljeni su da procijene kolegij Pogrešne predodžbe u prirodnim znanostima u svim aspektima, koristeći se evaluacijskim obrascem.

Obrazac za prikupljanje podataka bio je primijenjen kod studenata $\mathrm{u}$ eksperimentalnoj skupini, u obliku posttesta s vremenskim odmakom, dvije i pol 
godine nakon što je istraživanje bilo provedeno na sveučilištu. Sa sudionicima se stupilo u kontakt putem interneta, da bi im se pojasnio cilj istraživanja i važnost njihova sudjelovanja u ovom kasnijem dijelu istraživanja. Tako je provjerena ukorijenjenost pogrešnih predodžbi, iako su sudionici već radili kao nastavnici predmeta prirodnih znanosti u osnovnim školama u Turskoj. $U$ to je vrijeme radno iskustvo sudionika variralo $u$ rasponu od 1 do 2 godine.

\section{Obrazac za prikupljanje podataka}

Odabrane su tri tvrdnje među testovima sastavljenima za nastavu iz kolegija Pogrešne predodžbe u prirodnim znanostima da bi se prikupili podaci za ovo istraživanje. Te tvrdnje, koje su sastavljene nakon proučavanja relevantne literature, jesu sljedeće:

(1) Protoni jače privlače bliže elektrone nego udaljene elektrone.

(2) Razlog međusobnog nemiješanja nekoliko tekućina jest činjenica da su im gustoće različite.

(3) Dinamička ravnoteža je jednakost broja čestica u parnom stanju i broja čestica u tekućem stanju.

Te tvrdnje prezentirane su studentima na jeziku istraživanja - turskom. Stoga, da bi bile jasnije, mogu se detaljnije objasniti na sljedeći način.

U prvoj se tvrdnji navodi da protoni koji ostaju u jezgri atoma jače privlače različite elektrone. Ti elektroni koji se jače privlače jesu oni koji ostaju u orbitama koje su bliže središtu atoma - jezgri. Protoni slabije privlače vanjske elektrone (koji su udaljeniji od središta atoma). Od studenata se očekivalo sljedeće točno objašnjenje te tvrdnje: protoni privlače sve elektrone (i one koji su bliži i one koji su udaljeniji od središta atoma) jednakom jačinom. Međutim, ne djeluje na sve elektrone privlačna sila protona na jednak način. Razlog tomu je efekt zasjenjenja. Zasjenjenje znači blokiranje utjecaja privlačenja elektrona od protona, zbog drugih elektrona koji se kreću između toga elektrona i središta atoma. U zasjenjenju elektroni koji ostaju između vanjskih elektrona i jezgre atoma smanjuju silu privlačenja koja djeluje na vanjske elektrone od protona.

Da bismo drugu tvrdnju detaljno opisali, navodi se da, kada pomiješamo nekoliko tekućina, one mogu ostati u različitim slojevima. Ne miješaju se međusobno. Sve tekućine ostaju u različitim slojevima i tako oblikuju heterogenu strukturu. To se događa zbog toga što imaju različite gustoće. Od studenata se očekivalo da će dati sljedeće objašnjenje: razlog tomu što se dvije ili više tekućina međusobno ne miješaju povezan je s kemijskim privlačenjem, a ne s činjenicom da te tekućine imaju različite gustoće. Kada se tekućine međusobno pomiješaju, to znači da se jedna u drugoj otapaju i tako tvore homogenu masu. Odgovarajuće kemijsko privlačenje izaziva otapanje. Međutim, ako ne postoji kemijsko privlačenje, različite tekućine neće se međusobno pomiješati. Na primjer, polarne tvari otapaju se u polarnim otopinama ( $\mathrm{HCl}$ se otapa $\left.\mathrm{u}_{2} \mathrm{O}\right)$, a nepolarne se tvari otapaju u nepolarnim otopinama $\left(\mathrm{CCl}_{4}\right.$ se otapa $\left.\mathrm{u}_{6} \mathrm{H}_{6}\right)$. Međutim, polarne tvari ne otapaju se u nepolarnim otopinama $\left(\mathrm{H}_{2} \mathrm{O}\right.$ se ne otapa $\mathrm{u}_{6} \mathrm{H}_{6}$ ). 
U trećoj se tvrdnji navodi da je broj čestica u parnom stanju jednak broju čestica u tekućem stanju u dinamičkoj ravnoteži. Posebno se naglašava jednakost broja čestica u parnom i tekućem stanju. No, u očekivanom odgovoru trebalo bi naglasiti prijelazno stanje tvari iz tekućeg u parno stanje, kao i prijelaz iz parnog u tekuće stanje u fazi dinamičke ravnoteže. Tijekom tog procesa broj čestica koje prelaze u parno iz tekućeg stanja, kao i broj čestica koje prelaze iz tekućeg u parno stanje, je jednak.

Kako se može vidjeti, tri tvrdnje koje su bile uključene u obrazac za prikupljanje podataka povezane su s različitim temama iz područja kemije. Te tvrdnje odabrane su među temama koje su obrađene na nastavi u prvom, četvrtom i osmom tjednu. Prva je tvrdnja odabrana iz područja Čestična svojstva tvari (tema iz prvog tjedna), druga je odabrana iz područja Otopine (tema iz osmog tjedna), a treća iz područja Stanja tvari (obrađena u četvrtom tjednu nastave). U vrijeme kada je proveden predtest, studenti nisu imali nastavu o tim temama, pa su odgovarali na sva ta pitanja oslanjajući se isključivo na svoje predznanje. Kada je proveden međutest, tema koja je spomenuta u prvoj tvrdnji bila je obrađena na nastavi mjesec dana prije, a treća je bila obrađena na nastavi samo u eksperimentalnoj skupini. Međutim, tema spomenuta u drugoj tvrdnji uopće nije bila obrađena. S druge pak strane, očekivalo se da će studenti u eksperimentalnoj skupini razviti brojne kognitivne vještine da bi se uključili u raspravu o temama, te da će se tim vještinama koristiti pri odgovaranju na drugu tvrdnju, iako tema nije bila formalno obrađena na nastavi. U vrijeme provedbe posttesta sve su teme već bile obrađene na nastavi iz kolegija Pogrešne predodžbe u prirodnim znanostima, a posttest proveden je sa svim sudionicima na kraju semestra. K tomu, obrazac za prikupljanje podataka koristio se sa sudionicima kao posttest s vremenskim odmakom, i to dvije i pol godine nakon što je istraživanje provedeno.

Sudionici su trebali dati odgovore u obliku slaganja ili neslaganja s navedenim tvrdnjama i objasniti ih. Kao što se može vidjeti, sve tvrdnje sadržavale su pogrešne predodžbe. Činjenica da se studenti slažu s tvrdnjama, pokazuje da oni imaju pogrešne predodžbe o toj temi, što je vidljivo i u njihovim izjavama. No, studenti koji se ne slažu s pojedinom tvrdnjom mogli su dati znanstveno objašnjenje o toj tvrdnji, umjesto da su pogrešnu predodžbu prihvatili kao točan odgovor.

Osim toga, za studente iz eksperimentalne skupine pripremljen je evaluacijski obrazac s pitanjem otvorenog tipa: „Molimo vas, procijenite kolegij sa svih aspekata.“ Zamoljeni su da zapišu svoje dojmove o kolegiju uzimajući u obzir cijeli semestar, a ono što su pisali nije bilo vremenski ograničeno, niti je moralo biti određene duljine.

\section{Analiza podataka}

Odgovori koje su studenti dali na svaku tvrdnju analizirani su metodom analize sadržaja (Yıldırım i Şimşek, 2008, str. 227) i prikupljeni u 5 kategorija: točno, djelomično pogrešna predodžba, pogrešna predodžba, bez odgovora i nevažno. U daljnjem tekstu objašnjena je svaka od tih kategorija. Točno - odgovori koje su studenti dali u skladu su s njihovim znanstvenim znanjem. Djelomično pogrešna predodžba - 
odgovori koje su studenti dali djelomično su kontradiktorni znanstvenom znanju, a djelomično su u skladu sa znanstvenim znanjem. Pogrešna predodžba - odgovori koje su dali studenti potpuno su kontradiktorni znanstvenom znanju. Nevažno - odgovori koje su dali studenti spominju neke druge teme umjesto onoga što je spomenuto u tvrdnji. Bez odgovora - slučajevi u kojima studenti nisu dali nikakvo objašnjenje. Iz odgovora koje su dali studenti odabrani su primjeri za svaku kategoriju i uključeni su u poglavlje o rezultatima.

Za kvantificiranje podataka i komparaciju stupnjeva razumijevanja tijekom različitih dijelova nastave (predtest, međutest, posttest i posttest $s$ vremenskim odmakom) korištena je deskriptivna statistika. $\mathrm{K}$ tomu, provedeni su i Kruskal-Wallisovi $\mathrm{H}$ testovi da bi se utvrdilo postoji li značajna razlika između kontrolne i eksperimentalne skupine s obzirom na svaku tvrdnju navedenu u predtestu i posttestu. Štoviše, provedeni su Wicoxonovi sign-ranked testovi da bi se utvrdilo postoji li značajna razlika između rezultata na predtestu i posttestu koje su ostvarili studenti u istoj skupini za svaku tvrdnju. Da bi se podaci ponderirali, korištena je skala: 4 za točno, 3 za djelomično pogrešnu predodžbu, 2 za pogrešnu predodžbu, 1 za nevažno i 0 za kategoriju bez odgovora. Prikupljeni podaci kodirani su u Excel dokumentu i zatim prebačeni u SPSS 16.0 program da bi se proveli statistički testovi. Nisu se uspoređivali rezultati predtesta i međutesta, kao ni rezultati predtesta i posttesta s vremenskim odmakom. Postotak distribucije frekvencije $u$ obliku tablica bio je dovoljno dobar za prikazivanje trendova između rezultata predtesta, međutesta, posttesta i posttesta s vremenskim odmakom, a koji se tiču predodžbi studenata u eksperimentalnoj skupini.

Također, mišljenja studenata u eksperimentalnoj skupini vezana uz kolegij Pogrešne predodžbe u prirodnim znanostima tematski su obrađena metodom analize sadržaja i također su kvantificirana da bi se utvrdio njihov pristup tom kolegiju.

\section{Rezultati \\ Shvaćanja sudionika}

Razumijevanje sudionika vezano uz prvu tvrdnju - „Protoni jače privlače bliže elektrone nego udaljene elektrone“ - prikazano je u tablicama 1.i 2.

Tablica 1.

Kao što se može vidjeti u Tablici 1, rezultati predtesta pokazali su da je oko $12 \%$ sudionika iz eksperimentalne skupine dalo točne odgovore, a oko $62 \%$ imalo je pogrešne predodžbe. Oko $23 \%$ njih nije moglo dati nijedan odgovor. Rezultati međutesta pokazali su pozitivnu promjenu u odgovorima studenata u eksperimentalnoj skupini. Međutim, rezultati posttesta pokazali su pogrešne predodžbe, a rezultati posttesta $s$ vremenskim odmakom pokazali su djelomično pogrešne predodžbe $u$ odgovorima sudionika u eksperimentalnoj skupini u vezi s navedenom tvrdnjom.

Kada su Kruskal-Wallisovim $\mathrm{H}$ testom analizirani rezultati predtesta u kontrolnoj i eksperimentalnoj skupini u vezi s prvom tvrdnjom, nije pronađena značajna razlika 
između tih dviju grupa $c^{2}(1, N=52)=1,835, p=, 176$. S druge pak strane, rezultati Kruskal-Wallisova $\mathrm{H}$ testa pokazali su značajnu razliku između eksperimentalne $\mathrm{i}$ kontrolne skupine $\mathrm{u}$ rezultatima posttesta $\mathrm{c}^{2}(1, N=52)=6,015, p=, 014$.

Tablica 2.

Kako se može vidjeti u Tablici 2, analize Wilcoxonova signed-rank testa rezultata predtesta i posttesta eksperimentalne skupine pokazale su napredak u znanstvenim odgovorima studenata zahvaljujući primjeni metode rasprave $s$ ciljem postizanja konceptualne promjene $(\mathrm{z}=4,17, \mathrm{p}=, 0001)$. No, takav napredak nije utvrđen $\mathrm{u}$ rezultatima predtesta i posttesta studenata iz kontrolne skupine $(\mathrm{z}=0,212, \mathrm{p}=, 832)$.

Razumijevanje sudionika vezano uz drugu tvrdnju - „Razlog međusobnog nemiješanja nekoliko tekućina je činjenica da su im gustoće različite“ - prikazano je u tablicama 3 i 4.

Tablica 3.

Kako pokazuje Tablica 3, više od polovine studenata i iz eksperimentalne (oko 58\%) i iz kontrolne skupine (62\%) imalo je pogrešne predodžbe o drugoj tvrdnji u predtestu. Rezultati međutesta pokazali su napredak u odgovorima studenata iz eksperimentalne skupine, što se može vidjeti iz povećanog broja točnih odgovora (50\%) i smanjenog broja pogrešnih predodžbi (35\%) u usporedbi s rezultatima predtesta. U posljednjoj su fazi rezultati posttesta pokazali da je postotak preostalih pogrešnih predodžbi 23 , a da je postotak točnih odgovora bio 65 kod studenata iz eksperimentalne skupine. Rezultati posttesta s vremenskim odmakom također su bili slični rezultatima posttesta provedenog sa sudionicima u eksperimentalnoj skupini.

Kada se razumijevanje studenata iz obje skupine vezano uz tu tvrdnju analiziralo Kruskal-Wallisovim $\mathrm{H}$ testom, nije utvrđena nikakva značajna razlika među njima c2 $(1, N=52)=1,322, p=, 250$. Međutim, statistika Kruskal-Wallisova $\mathrm{H}$ testa otkrila je značajnu razliku u rezultatima kontrolne i eksperimentalne skupine na posttestu c2 $(1, N=52)=6,015, p=, 014$.

Tablica 4.

Kao što se može vidjeti u Tablici 4, statistika Wilcoxonova signed-rank testa pokazuje povećan broj točnih odgovora studenata u eksperimentalnoj skupini nakon provedene nastave $(\mathrm{z}=3,31, \mathrm{p}=, 001)$. Međutim, takav napredak nije utvrđen Wicoxonovim signed-rank testom kod studenata iz kontrolne skupine $(\mathrm{z}=0,212, \mathrm{p}=, 832)$.

Razumijevanje sudionika vezano uz treću tvrdnju - „Dinamička ravnoteža je jednakost broja čestica u parnom stanju i broja čestica u tekućem stanju“ - prikazano je u Tablicama 5 i 6.

Tablica 5.

Kada se prouči Tablica 5, jasno je da postoje značajne razlike u postotku točnih odgovora i pogrešnih predodžbi u rezultatima predtesta i posttesta. Rezultati pokazuju napredak u konceptualizaciji kod studenata iz eksperimentalne skupine, a u kontrolnoj su 
skupini rezultati obrnuti. Međutim, rezultati posttesta s vremenskim odmakom upućuju na to da sudionici iz eksperimentalne skupine još uvije imaju pogrešne predodžbe.

Iako statistika Kruskal-Wallisova $\mathrm{H}$ testa nije pokazala značajnu razliku između odgovora studenata iz eksperimentalne i kontrolne skupine na predtestu u prvoj fazi istraživanja,c2 $(1, N=52)=1,322, p=, 250$, rezultati posttesta u trećoj fazi pokazali su značajnu razliku između njih c2 $(1, N=52)=23,415, p=, 0001$.

Tablica 6.

Tablica 6 pokazuje da je statistikom Wilcoxonova signed-rank testa utvrđena značajna razlika u rezultatima koje su studenti u eksperimentalnoj skupini ostvarili na predtestu i posttestu, kao što je bio slučaj i u prethodnim rezultatima, što potvrđuje pozitivan utjecaj metode rasprave $s$ ciljem postizanja konceptualne promjene na točne odgovore studenata $(\mathrm{z}=4,72 ; \mathrm{p}=, 0001)$. No, takva razlika nije pronađena $\mathrm{u}$ rezultatima studenata iz kontrolne skupine na predtestu i posttestu $(\mathrm{z}=.099 ; \mathrm{p}=, 921)$.

Tablica 7 prikazuje neke primjere stavova studenata koji ilustriraju svaku kategoriju koja se koristila $\mathrm{u}$ analizi tvrdnji.

Tablica 7

Primjeri stavova sudionika

\begin{tabular}{|c|c|c|}
\hline $\begin{array}{l}\text { Pitanje } \\
\text { br. }\end{array}$ & Kategorija & Stavovi sudionika \\
\hline \multirow[t]{4}{*}{1} & Točno & $\begin{array}{l}\text { Na svaki elektron djeluje ista privlačna sila. Međutim, svaki elektron na nju } \\
\text { reagira drugačije. }\end{array}$ \\
\hline & $\begin{array}{l}\text { Djelomično pogrešna } \\
\text { predodžba }\end{array}$ & Privlačna sila protona smanjuje se sa zasjenjenjem kada se elektroni gibaju. \\
\hline & Pogrešna predodžba & Bliže elektrone protoni privlače jače nego udaljenije elektrone. \\
\hline & Nevažno & $\begin{array}{l}\text { Znam da elektroni ne padaju na jezgru zbog svoje brzine. Razlog zašto se to } \\
\text { ne događa usprkos privlačnoj sili protona je činjenica da na bliže elektrone } \\
\text { djeluje jača privlačna sila jer " }+^{\prime \prime} \text { privlači }{ }_{\text {,-". }} \mathrm{F}=\mathrm{q}_{1} \mathrm{q}_{2} / \mathrm{d}^{2} \text { (F se smanjuje kada se } \mathrm{d} \\
\text { smanjuje.) }\end{array}$ \\
\hline \multirow[t]{4}{*}{2} & Točno & $\begin{array}{l}\text { Tekućine se ne miješaju zbog svojeg polariteta. To je također povezano s } \\
\text { otapanjem. Na primjer, usprkos činjenici da su gustoće vode i alkohola različite, } \\
\text { oni se otapaju jedno u drugom jer su obje polarne tekućine. }\end{array}$ \\
\hline & $\begin{array}{l}\text { Djelomično pogrešna } \\
\text { predodžba }\end{array}$ & $\begin{array}{l}\text { Razlog zašto se nekoliko tekućina međusobno ne miješa mogao bi biti povezan } \\
\text { s razlikom u gustoći. Međutim, to nije jedini razlog. Polaritet također utječe na } \\
\text { to. }\end{array}$ \\
\hline & Pogrešna predodžba & $\begin{array}{l}\text { Kada postoji razlika u gustoći, gušća tekućina spušta se na dno, dok ona čija je } \\
\text { gustoća manja ostaje iznad nje, te se ne miješaju. }\end{array}$ \\
\hline & Nevažno & Koncentracije tekućina su različite te se one međusobno ne miješaju. \\
\hline \multirow[t]{4}{*}{3} & Točno & $\begin{array}{l}\text { U dinamičkoj ravnoteži, broj čestica koje prelaze iz parnog stanja u tekuće stanje } \\
\text { jednak je broju čestica koje prelaze u parno stanje iz tekućeg stanja. }\end{array}$ \\
\hline & $\begin{array}{l}\text { Djelomično pogrešna } \\
\text { predodžba }\end{array}$ & $\begin{array}{l}\text { Ne možemo zasigurno reći da postoji jednakost u dinamičkoj ravnoteži. } \\
\text { Međutim, postoji pokušaj da se kontinuirano zadrži ravnoteža. Ponekad su broj } \\
\text { čestica u parnom stanju i broj čestica u tekućem stanju jednaki. }\end{array}$ \\
\hline & Pogrešna predodžba & $\begin{array}{l}\text { Dinamička ravnoteža je moment kada je broj molekula u plinovitom stanju } \\
\text { jednak broju molekula u tekućem stanju prilikom vrenja. }\end{array}$ \\
\hline & Nevažno & $\begin{array}{l}\text { Ako nema ravnoteže, ne događaju se nikakve reakcije. Ravnoteža je uvijek } \\
\text { prisutna. }\end{array}$ \\
\hline
\end{tabular}




\section{Mišljenja sudionika iz eksperimentalne skupine o kolegiju Pogrešne predodžbe u prirodnim znanostima}

Kada su sudionici iz eksperimentalne skupine zamoljeni da procijene kolegij Pogrešne predodžbe u prirodnim znanostima sa svih aspekata, prikupljena su njihova mišljenja, prikazana u Tablici 8. Kako je svaki student mogao pisati o više tema, ukupna frekvencija tema već je od ukupnog broja studenata u eksperimentalnoj skupini.

Tablica 8

Mišljenja sudionika iz eksperimentalne skupine o kolegiju Pogrešne predodžbe u prirodnim znanostima

\begin{tabular}{lcc}
\hline Tema & $f$ & $\%$ \\
\hline Pomogao mi je otkriti i ukloniti moje pogrešne predodžbe. & 18 & 28,6 \\
Provedba kolegija bila je djelotvorna i uspješna. & 14 & 22,2 \\
Ovo je neophodan i koristan kolegij. & 6 & 9,5 \\
Ovo bi trebao biti obvezan kolegij za sve studente. & 6 & 9,5 \\
Ovaj kolegij trebao bi biti ponuđen i u drugim granama (fizika i biologija). & 5 & 7,9 \\
Jako mi je drago što sam odabrao/odabrala ovaj kolegij. & 4 & 6,3 \\
Kolegij bi trebao biti ponuđen u ranijim semestrima. & 3 & 4,8 \\
Kolegij mi je povećao samopouzdanje. & 3 & 4,8 \\
Koristit ću istu metodu kada budem radio/radila kao nastavnik. & 2 & 3,2 \\
Teme obrađene na kolegiju trebale bi biti ograničene na osnovni stupanj. & 2 & 3,2 \\
\hline Ukupno & 63 & 100,00 \\
\hline
\end{tabular}

Većina mišljenja studenata u eksperimentalnoj skupini bila je pozitivna, kao što je prikazano u Tablici 8 . Ti sudionici smatrali su da je kolegij uklonio njihove pogrešne predodžbe tako što im je pomogao da ih prepoznaju. Također su naveli da im je metoda korištena u kolegiju dala dodatnu perspektivu i da je tako kolegij uspješno završen. Studentima je drago što su odabrali taj kolegij i naveli su da će se istom metodom koristiti u svojoj budućoj nastavničkoj karijeri. Ti rezultati potvrđuju da je kolegij ostvario svoje ciljeve.

\section{Rasprava i zaključci}

Rezultati istraživanja mogu se sažeti u dvije skupine - kognitivne i afektivne rezultate. Shodno tome, s obzirom na kognitivne rezultate, očito je da se postotak točnih odgovora povećao i da je većina pogrešnih predodžbi uklonjena s pomoću metode rasprave s ciljem postizanja konceptualne promjene. Taj je rezultat paralelan $s$ istraživanjem koje je proveo Eryılmaz, a koje je pokazalo učinkovitost te metode pri uklanjanju pogrešnih predodžbi o sili i gibanju (2002). Također, rezultati predtesta pokazali su odgovore nevažne za drugo pitanje. Rezultat je sličan ranijim rezultatima istraživanja koje su dobili Güneş i sur. (2010). Međutim, rezultati posttesta pokazuju da se takvi odgovori nisu pojavili na kraju istraživanja.

Razlog provođenja međutesta je taj što su teme povezane s prvim pitanjem bile obrađene na nastavi. Međutim, tema povezana s drugim pitanjem nije bila obrađena na 
nastavi, a tema povezana s trećim pitanjem bila je obrađena tek malo prije provođenja međutesta. Zbog tog je razloga provedena međuanaliza da bi se provjerilo kako se predodžbe studenata mijenjaju s obzirom na teme obrađene na nastavi. Također, namjera nam je bila promatrati mogu li studenti primijeniti svoje vještine propitivanja na teme koje još nisu obrađene na nastavi, iako je razdoblje evaluacije kraće. Provedba posttesta omogućila je istraživačima provesti cjelovitu evaluaciju učinkovitosti metode rasprave s ciljem postizanja konceptualne promjene.

Kako je navedeno u Tablicama 1, 3 i 5, kod studenata u eksperimentalnoj skupini postotak točnih odgovora na sva tri pitanja povećavao se od predtesta do posttesta na kraju semestra. Taj rezultat upućuje na to da je postotak uklanjanja pogrešnih predodžbi visok. Također, ide mu u prilog i smanjenje broja djelomično pogrešnih predodžbi tih studenata. Takav napredak nije utvrđen u razumijevanju kod studenata u kontrolnoj skupini na kraju semestra. Više od polovine sudionika u kontrolnoj skupini imalo je pogrešne predodžbe i na predtestu i na posttestu, pri odgovorima na prvu i drugu tvrdnju. Visok postotak pogrešnih predodžbi i relativno nizak postotak točnih odgovora upućuju na potrebu za konceptualnom promjenom kod sudionika u kontrolnoj skupini.

Kada se analiziraju rezultati posttesta s vremenskim odmakom, može se vidjeti da nekoliko sudionika iz eksperimentalne skupine ima pogrešne predodžbe usprkos činjenici da su već stekli nastavničko iskustvo. Taj rezultat upućuje na to da su njihove pogrešne predodžbe duboko ukorijenjene (Viennot, 1979, str. 205; citirano u Posner i sur., 1982). Pogrešne predodžbe mogu se kod pojedinaca ponovno pojaviti nakon nekog vremena.

U ovom je istraživanju pokazano da su pogrešne predodžbe vezane uz drugo pitanje više ukorijenjene nego neke druge. Razlog tomu može biti činjenica da tvrdnja obuhvaća više od jedne teme (otopine, mješavine, veze, tvari). Stoga se od studenata zahtijeva da razmotre više tema kao cjelinu, za što su potrebne metakognitivne vještine. $\mathrm{K}$ tomu, kako je prikazano u distribucijama frekvencije - postotka, smanjenje broja odgovora u kategorijama Bez odgovora i Nevažno također je značajno. To pokazuje da na kraju semestra studenti koji su odabrali kolegij Pogrešne predodžbe u prirodnim znanostima razvijaju svoje mišljenje kod pitanja na koja na predtestu nisu imali odgovore ili su ti odgovori bili nevažni.

Detaljna evaluacija koju su odradili studenti u eksperimentalnoj skupini u posljednjoj fazi istraživanja pokazuje afektivne rezulate istraživanja tako što dokazuje učinkovitost metode, te pokazuje pozitivna mišljenja studenata. Odgovori koji pokazuju povećanje samopouzdanja, učinkovitu nastavu iz tog kolegija, upute za buduću nastavu i zadovoljstvo odabranim kolegijem afirmativnog su tipa. Ti studenti stekli su različita gledišta dok su pretraživali članke vezane uz teme zadane za taj kolegij.

Takvi bi se rezultati mogli prikazati kao rješenja problema utvrđenih u istraživanjima koja su proveli Halim i Meerah (2002), Kahyaoğlu i Yavuzer (2004), Karamustafaoğlu (2009) i Canbazoğlu, Demirelli i Kavak (2010). 
U svjetlu rezultata istraživanja sljedeće preporuke mogle bi doprinijeti konceptualnoj nastavi u području obrazovanja nastavnika iz grupe predmeta prirodnih znanosti:

(i) Metoda rasprave s ciljem postizanja konceptualne promjene može se koristiti pri uklanjanju pogrešnih predodžbi.

(ii) Teme iz fizike i biologije mogu se dodati gradivu kolegija tako što bi se povećao broj bodova koje nosi taj kolegij ili bi se za teme iz biologije i fizike mogli održavati posebni kolegiji.

(iii) Taj bi kolegij trebao biti obvezan, a ne izborni kolegij, na fakultetima na kojima se školuju budući nastavnici.

(iv) Kolegij bi se mogao održavati tijekom 5. i 6. semestra u četverogodišnjim studijskim programima, ili tijekom 7.i 8. semestra u petogodišnim programima, da bi se odgovorilo na potrebe budućih nastavnika.

\section{Ograničenja}

Polustrukturirani intervjui mogli bi se provesti sa studentima u eksperimentalnoj skupini tijekom druge faze istraživanja, da bi se utvrdilo utječe li metoda diskusije s ciljem postizanja konceptualne promjene pozitivno na odgovore studenata na međutestu, pogotovo kod tema koje nisu bile obrađene na nastavi. Na taj bi način rezultati međutesta mogli biti funkcionalniji. 